\title{
Visitors' background as a factor in geosite evaluation. The case of Cenozoic volcanic sites in the Pogórze Kaczawskie region, SW Poland
}

\author{
Milena Różycka, Piotr Migoń \\ University of Wroctaw, Institute of Geography and Regional Development, \\ pl. Uniwersytecki 1, 50-137 Wroctaw; \\ e-mail:milena.rozycka@uwr.edu.pl,piotr.migon@uwr.edu.pl
}
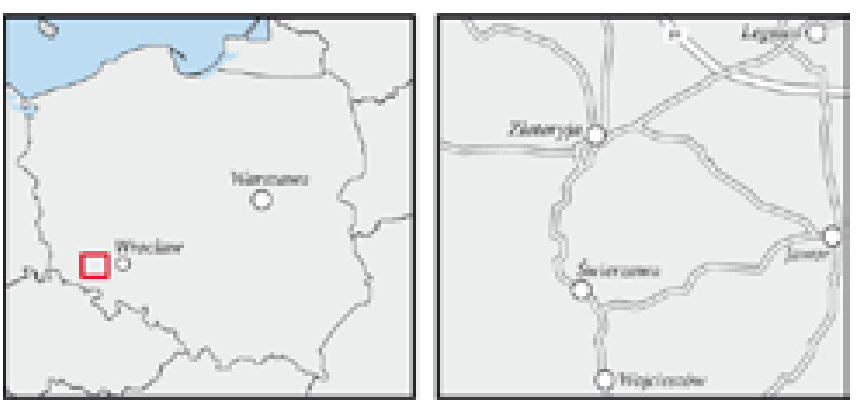

Abstract: The paper presents a new approach to geosite assessment in which individual preferences and needs of visitors with different backgrounds, i.e. knowledge of Earth science and interest in geoheritage, are taken into account. The aim of the study is to analyze how perspectives of visitors, split into three different categories (viz. geo-expert, interested visitor and unaware visitor), may affect evaluation of geosites. Parallel evaluations of a group of 11 geosites in the Pogórze Kaczawskie region representing mid-Cenozoic volcanism have been carried out and their results compared. Emphasis on different criteria resulted in considerable changes in the positions of certain geosites in the rankings. Based on the assumption that attractiveness of a geosite may be also perceived variously depending on the season, the attempt has been made to include 'seasonal factor', i.e. the role of vegetation that obscures the visibility of geological and geomorphological features, in the assessment procedure. Shifts in position of individual geosites were generally minor but this may be related to a small sample used in this pilot study.

Key words: geosite assessment, visitor typology, volcanism, Sudetes

\section{Introduction}

There is a multitude of methodological approaches to quantitative assessments of geosites presented in the literature (e.g. Bruschi, Cendrero, 2005, 2011; Coratza, Giusti, 2005; Pereira et al., 2007; Reynard et al., 2007; Zouros, 2007; Migoń, Sobczyk, 2009; Lima et al., 2010; Rybár, 2010; Feuillet, Sourp, 2011; Coratza et al., 2012). Individual researchers adopt various criteria and assign them variable weights, hence the ongoing debate whether these procedures are truly objective evaluations or rather manifestations of subjective judgements of their authors. For example, Štrba et al. (2015) have recently evaluated three geosites in Slovakia using several different methods proposed previously and observed that the resultant rankings were not identical. A further problem in quantitative geosite assessment is that not many of them take explicitly into account different priorities of visitors with dissimilar state of knowledge of Earth science. Rather, they tend to reflect an expert knowledge of geoscientists involved in geosite evaluation. A notable exception is a variant approach that has been to some extent developed in recent years by Serbian authors. They include the opinion of visitors to geosites into the assessment procedure by the application of M-GAM ('modified geosite assessment model') in which the importance of selected criteria from their perspective was determined (Božić et al., 2014; Tomić, Božić, 2014).

Geotourism market is highly diversified (Hurtado et al., 2013) and consists of tourists with different backgrounds, ranging from experts to casual (unaware) tourists (Grant 2010, Dowling 2011). Consequently, people with different prior knowledge may be expected to select the geosites they want to visit using not exactly the same criteria. Likewise, their experience from a visit may vary, depending on how they perceive different values of a site. Therefore, from the perspective of different geotourism market segments and in terms of attractiveness each geosite performs in various ways and if so, attractiveness should be understood as a relative term.

Tourists with various levels of knowledge of geology, geomorphology and other related fields will likely appreciate different values of a site and this should be considered when assessing the importance of different criteria in the evaluation process. It may be generally postulated that geotourists sensu stricto, i.e. visitors with considerable background and high motivation derived from the need to increase their knowledge, are mostly interested in intrinsic values of a geosite itself, e.g. scientific or educational, whereas attention of casual visitors is frequently attracted by other aspects of a site, not necessarily associated with geoheritage. This situation is related to the fact that their motivations and interests in geoscience are usually very limited. In that case, the attractiveness of an object would be perceived mostly in the light of its external features, e.g. accessibility or aesthetics of the surrounding landscape. Geotourists seem to be less influenced by those factors. Among them, experts (Dowling, 2011) 
constitute a special category of visitors to geosites, with the widest knowledge in the field. Their professional background may translate into specific priorities when choosing geosites to visit as this group is particularly expected to select objects of high scientific importance and perceive them as notably attractive regardless of other factors, whether these enhance the overall value of the site or interfere with geoscientific value. It is likely that in the case of non-professional geotourists and casual tourists educational value of geosite would be more important than scientific one when determining attractiveness of an object.

The aim of this paper is to illustrate how explicit consideration of the profile of visitors and their specific preferences and needs might influence the final result of the assessment procedure. For this purpose a small number of geosites related to Cenozoic volcanism at the Pogórze Kaczawskie region were selected for evaluation. Some of them have already been subjected to numerical assessment (Cedro et al., 2009; Migoń, Pijet-Migoń, 2010), however their geotourism attractiveness has been determined from a unilateral point of view. In addition, in the closing part of the paper vegetation is introduced as a 'correcting factor' since its considerable growth may severely affect the visibility and appeal of a geosite. Hence, perception of a site may also differ depending on season.

This paper should be thus considered as a pilot study and methodological proposal, subject to further refinement and testing on both a larger sample and using different methods. Here, for the purpose of this exercise, we simultaneously play the role of visitors with different backgrounds ourselves, assuming what their priorities might be and how they would vary.

\section{Study area}

\section{General setting of Pogórze Kaczawskie region}

The region of Pogórze Kaczawskie (= Kaczawskie Foothills) is located in the north-western part of the Sudetes and is a low-altitude terrain of subdued relief, locally enhanced by residual bedrock hills built of more resistant rock types and deeply incised sections of river valleys. Long known among professionals for varied geology and polygenetic morphology (e.g. Dylikowa, 1952; Birkenmajer, 1967; Grocholski, 1967; Grocholski, Jerzmański, 1975; Kryza, 2008), for the last two decades it has been promoted as a geotourist destination, with relicts of ancient volcanism as one of the main assets (Grocholski, Wiśniewski, 1995; Bogdański, 2004; Pijet-Migoń, Migoń, 2009; Migoń, Pijet-Migoń, 2010; Migoń, 2014). In tourist promotion the phrase 'Land of Extinct Volcanoes' is used and while it is not entirely correct from the scientific viewpoint, it highlights the unique position of the region in Poland. Volcanic rocks from three different periods of volcanism occur here, including the most scenic and most represented sites where Cenozoic basalts and related rocks occur (Birkenmajer, 1967; Placek, 2007). Outcrops of Cenozoic volcanic rocks and landforms developed upon them were reported in a range of academic publications which form the basis for selecting localities for geotourism development. In this paper we focus on 11 such localities from the eastern and central part of the region (Fig. 1). A few, but not all localities have been subject to numerical evaluation before (Cedro et al.,
2009; Migoń, Pijet-Migoń, 2010) and both groups of authors commented about inadequate exposure and facilities at most of them. Only open access sites are considered in this paper. Working quarries, which may be visited by pre-arranged professional parties, are excluded as they are essentially off-limits to individual tourists, even if in terms of visibility of volcanism-related structures they may surpass open sites.

\section{Characteristics of Cenozoic volcanism geosites}

Bazaltowa. The broad dome of Bazaltowa (367 m) rises from the fault-generated boundary escarpment of the Sudetes and overlooks the piedmont plain by approximately $100 \mathrm{~m}$. However, its natural slopes hardly exceed $20^{\circ}$. The mountain top is flat, covered by predominantly oak forest. The main geosite at Bazaltowa is an abandoned quarry in its eastern slope, with the former exploitation scarp $100 \mathrm{~m}$ long and up to $25 \mathrm{~m}$ high. Although partly overgrown after tens of years of disuse, it still offers an insight into the internal structure of the volcanic edifice. The colonnade of moderately thick and slightly twisted vertical columns extends for c. $20 \mathrm{~m}$ in the northern quarry corner. Another abandoned quarry is located on the north-western slope but is less regular in shape and densely vegetated, hence much less suitable as a complementary geosite. A stone viewing tower was built on the hilltop surface in the early $20^{\text {th }}$ century, but has lost his function since due to tree growth in the vicinity. However, it remains an interesting object of local cultural landscape. The upper quarry rim acts as a viewing platform from which a part of the Sudetic Foreland can be seen. Bazaltowa can be reached by both a marked tourist trail and an educational trail from the nearby village of Paszowice.

Czartowska Skala. The conical hill of Czartowska Skała (Devil's Rock) is a prominent local landmark, rising above a nearly flat, open terrain in the water divide setting (Fig. 2). The hill is among the highest in the region (468 $\mathrm{m}$ ) and a good vantage point, with the view towards the Karkonosze Mts, weather permitting. An old quarry undercuts the western, southern and eastern slopes of the hill, revealing a simple fanlike pattern of columnar jointing. According to Birkenmajer (1967), volcanic activity occurred in a single phase and Czartowska Skała is a typical neck. No particular cultural values are associated with the hill. The "Trail of Extinct Volcanoes" connects Czartowska Skała with other sites of interest nearby.

Diablak. This a collective name given to four closely spaced basalt outcrops protruding in a straight line through the slope and crest of a prominent cuesta ridge. Most imposing is the lowermost outcrop, sculpted into a narrow wall, partly undercut by abandoned exploitation sites. Here narrow, inclined or horizontal columns are exposed and form tall cliffs more than $10 \mathrm{~m}$ high. A local geological curiosity is a $2 \mathrm{~m}$ long xenolith of Cretaceous sandstone which shows thin columnar jointing too (Fig. 3). This thermal phenomenon in xenoliths is known from two places only in the Polish part of the Sudetes. Whilst access to Diablak is technically easy, the outcrop is far away from marked trails and not developed for tourism. No particular cultural values are associated with the hill.

Górzec. Basaltic plug of Górzec $(445 \mathrm{~m})$ is the highest elevation at the marginal escarpment of the Sudetes in the Pogórze Kaczawskie sector of the mountain front. Probably because of distance from settlements it has never been 
intensively quarried and most of its slopes retained natural morphology. An insight into the structure of the volcanic body is provided by low $(<2 \mathrm{~m})$ summit and upper slope crags which show fairly regular, inclined columnar jointing. Otherwise the slopes are covered by an extensive block field, largely overgrown, probably a testament to efficient rock breakdown in the periglacial climate of the Pleistocene (Migoń et al., 2002). Evidence of anthropic impact includes a moat of a medieval hilltop fort and an engineered path to the summit flat, where a simple $18^{\text {th }}$ century chapel on the top is located. Górzec is a pilgrimage site of local importance, with the Way of the Cross going to the summit from the nearby village of Męcinka. Remnants of former ore mining (adits, waste heaps) can be found on the lower slopes (Maciejak K., Maciejak K., 2006). Several marked trails pass in the vicinity of Mt Górzec. Basalts of Górzec were $\mathrm{K}-\mathrm{Ar}$ dated for approximately $34 \mathrm{Ma}$ (Birkenmajer et al., 2007).
Grodziec. The cupola of Grodziec (389 m) is one among the most distinct elevations in the region, built of Cenozoic volcanic rocks. Its relative height attains $120 \mathrm{~m}$ and the flattish surroundings reinforce its geomorphic significance (Fig. 4). However, bedrock outcrops on slopes, including columnar jointing, are rare and mostly overgrown. Morphology of the summit part has been considerably modified by humans. The hilltop castle was built in the $14^{\text {th }}$ century and subsequently extended, but occupation of the summit is even of an earlier date. The present-day appearance of the castle partly reflects $19^{\text {th }}$ and early $20^{\text {th }}$ century reconstructions. Nevertheless, Grodziec castle is among the most significant cultural heritage objects in the area. One of castle towers is a good vantage point. The castle is open to visitors and accessible by car. Several marked trails go to the summit and the castle. Nephelinites of Grodziec were K-Ar dated for approximately $32 \mathrm{Ma}$ (Badura et al., 2005).

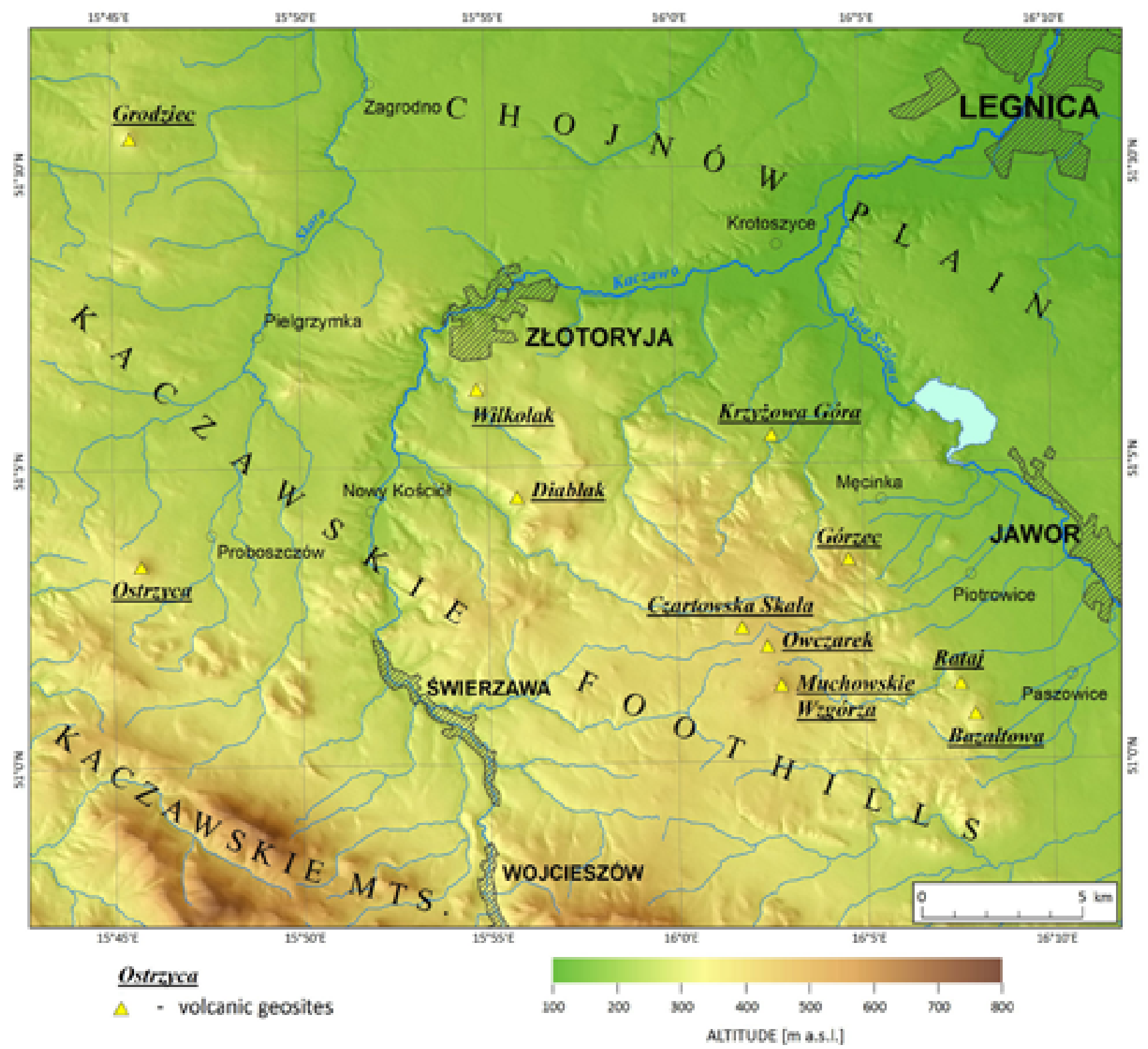

Fig. 1. Location map (courtesy Kacper Jancewicz) 


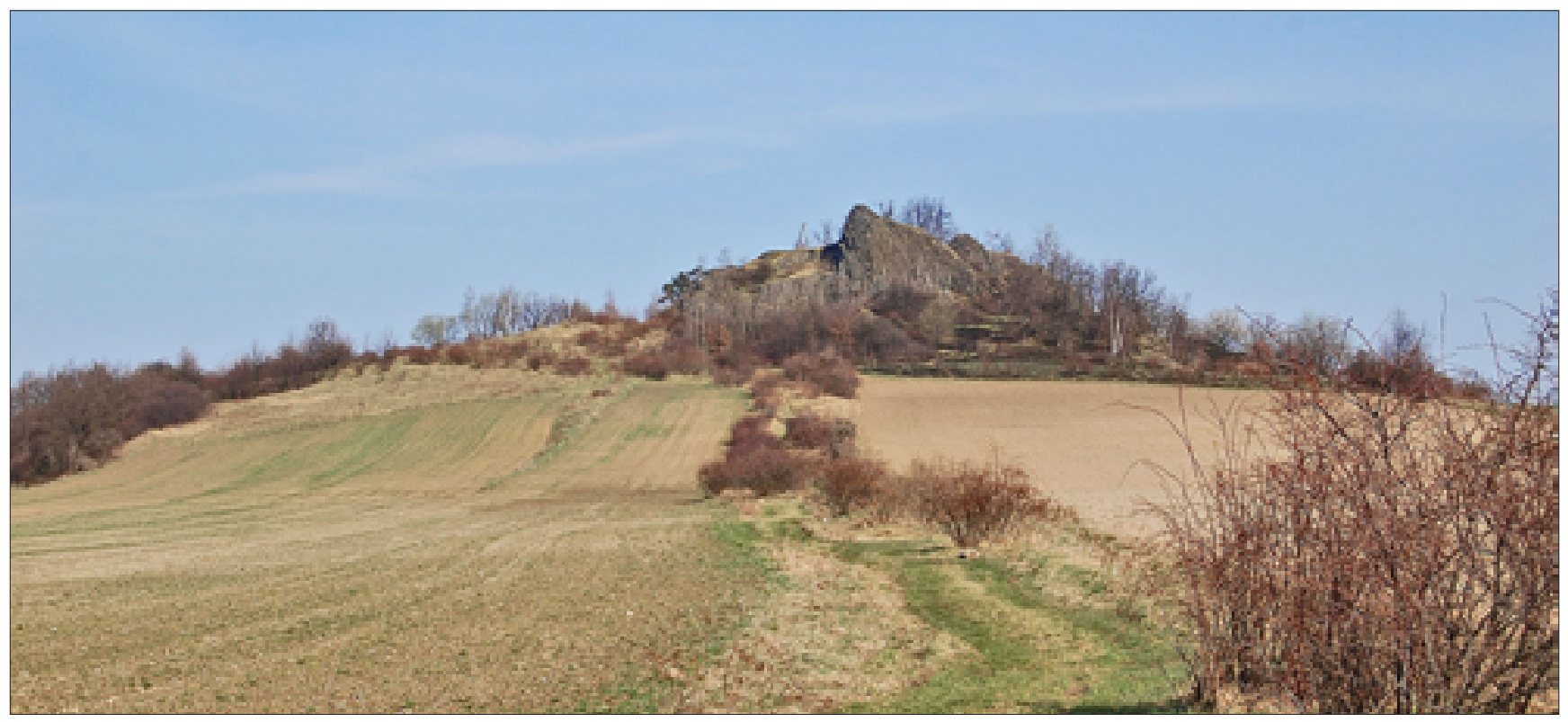

Fig. 2. Conical shape of Czartowska Skała, photo P. Migoń

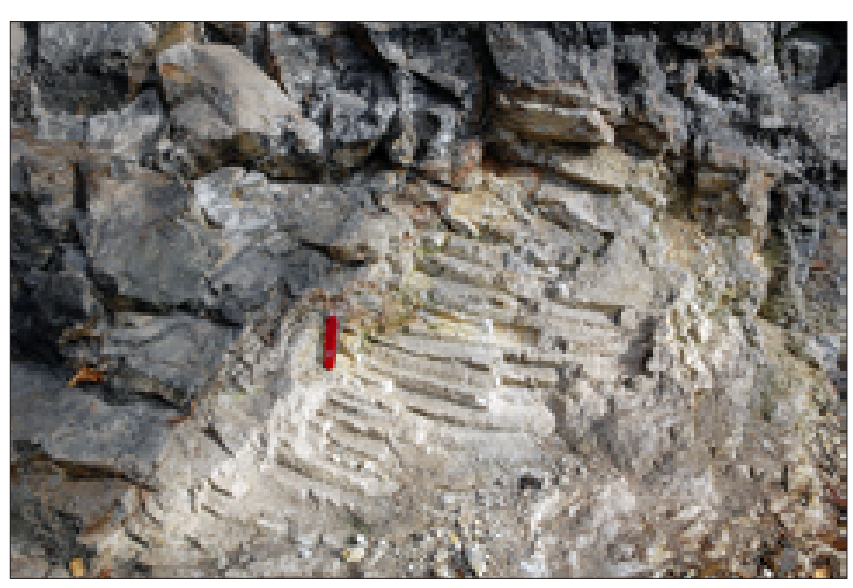

Fig. 3. Sandstone xenoliths in basalt, with thin columnar jointing, exposed at the southern tip of the rock crag of Diablak, photo P. Migoń
Krzyżowa Góra. The rather subdued elevation of Krzyżowa Góra $(250 \mathrm{~m})$ is included into this study because of two reasons. First, a former quarry wall exposes well-developed columnar jointing. It dips at a low angle to the north, suggesting that the main basaltic body was located further south and has been completely eroded away (Birkenmajer, 1967). Second, the site is located next to a local road which makes it easily accessible. Basalts of Krzyżowa Góra were $\mathrm{K}-\mathrm{Ar}$ dated for approximately $28 \mathrm{Ma}$ (Birkenmajer et al., 2007). Despite low altitude the top of the hill serves as a good vantage point due to an open terrain around. An old cross erected above the quarry is of rather minor cultural value.

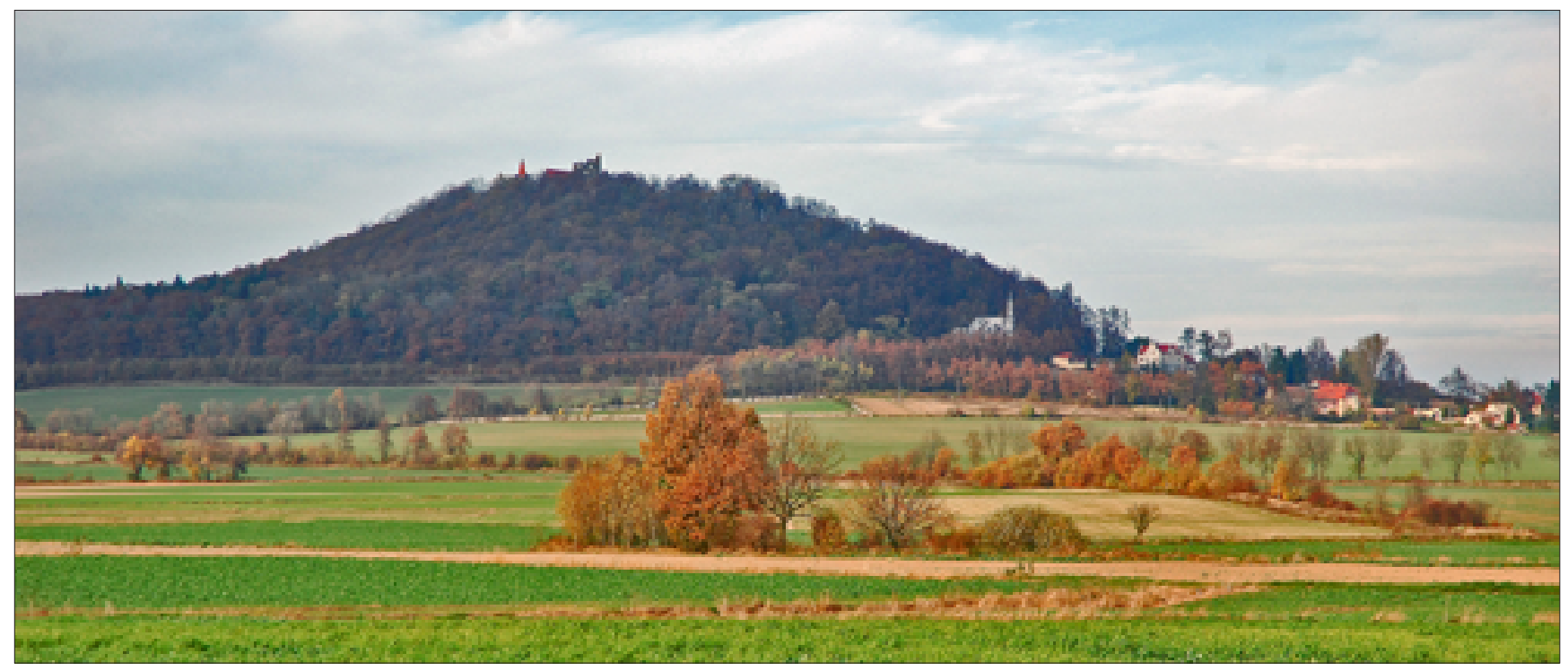

Fig. 4. Dome-shaped elevation of Grodziec, with partially restored castle ruins on the top surface, photo P. Migoń 


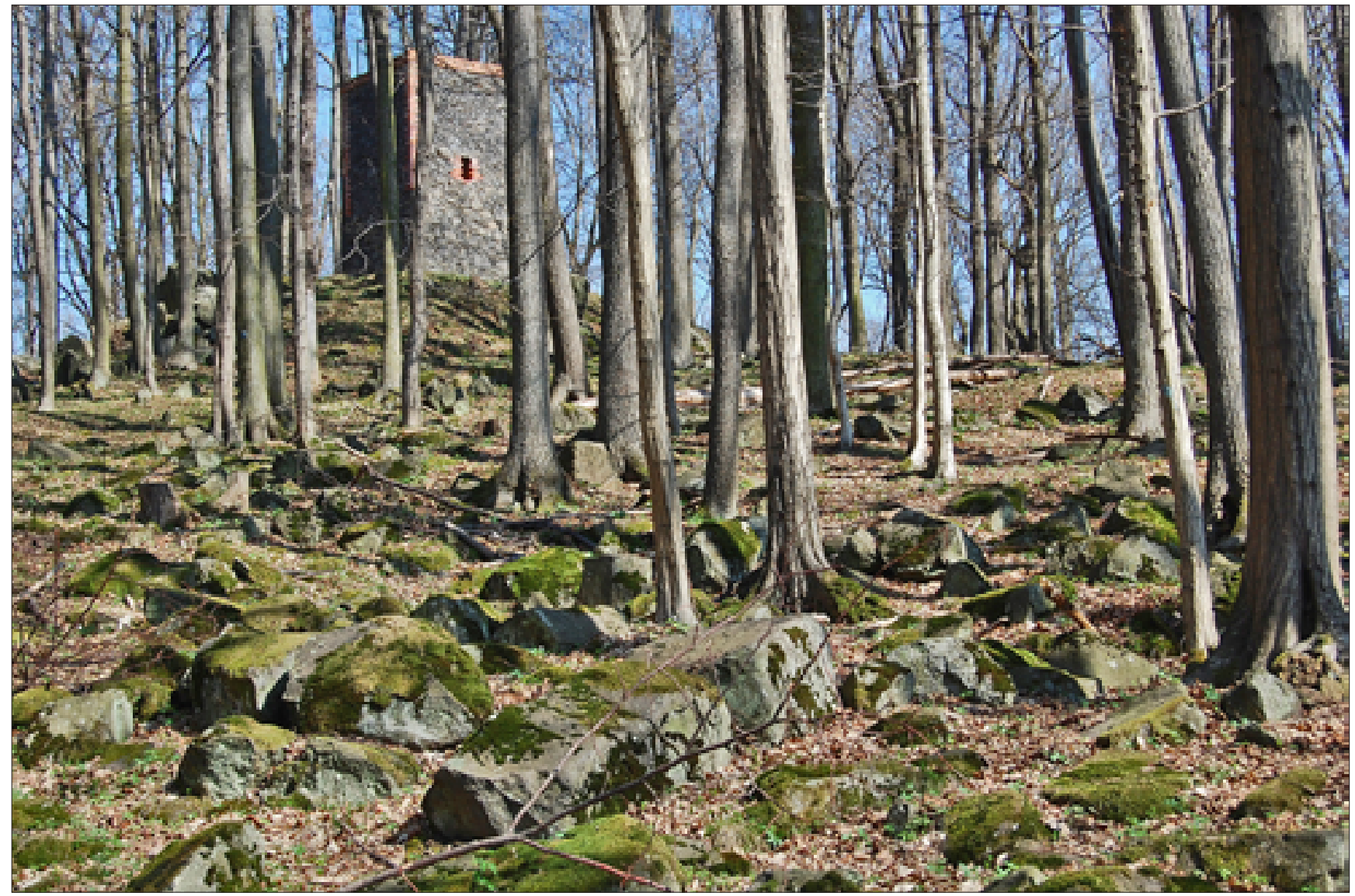

Fig. 5. Block and debris covers on forested slopes of Muchowskie Wzgórza, photo P. Migoń

Muchowskie Wzgórza. The largest continuous basalt outcrop in the region forms an elevation c. $2.5 \mathrm{~km}$ long and up to $1.5 \mathrm{~km}$ wide, with the highest point reaching $475 \mathrm{~m}$ and hence, $80-100 \mathrm{~m}$ above the surrounding upland surface. However, slopes are rather gentle, hardly exceeding $12^{\circ}$, except 2-6 m high cliffs in the crest part. The geological form of the outcrop is not definitively determined. Most likely, it is a remnant of a lava flow supplied by a central edifice (Grocholski, Jerzmański, 1975). K-Ar dating yielded an age of $31.6 \mathrm{Ma}$ (Badura et al., 2005). Columnar jointing is occasionally exposed and occurs in two variants. Regular thin, inclined columns can be seen in a small abandoned quarry cut into the western tip of the crest, whilst thick columnar compartments are present in some summit crags. The slopes are extensively covered by blocky mantle, interpreted as periglacial heritage (Fig. 5), whereas low basalt steps were likened to frost-riven cliffs and cryoplanation terraces (Migoń et al., 2002). Evidence of direct human impact is limited. Local curiosities include an early $20^{\text {th }}$ century viewing tower and a former border stone. The area is outside the regional network of marked trails, except a poorly maintained path to the western culmination.

Ostrzyca. The regular cone of Ostrzyca $(501 \mathrm{~m})$ is the highest peak in the region and the most prominent hill built of Cenozoic volcanic rocks. In addition, it has never been quarried on a large scale and its slopes retained geomorphic features inherited from cold climatic conditions of the Pleistocene. These include summit and mid-slope crags and cliffs, some as tall as $8 \mathrm{~m}$, narrow defiles, extensive scree covers, and boulder tongues (Baraniecki, 1952; Migoń et al., 2002). On the south-facing slopes scree is bare and extends for more than $50 \mathrm{~m}$ in downslope direction (Fig. 6). Crags and cliffs expose columnar jointing of basalt of variable geometry, from nearly vertical to almost horizontal, projecting out of slope surfaces. The summit crag is a good vantage point. Geomorphological values are supplemented by biotic values, which have become a basis to establish a nature reserve in the most elevated part of the hill (in existence since 1962) (Aniol-Kwiatkowska, Świerkosz, 1992). Anthropic impact on the landscape is limited to remnants of a small tourist lodge and World War II trenches around the hill. A few marked trails connect Ostrzyca with villages nearby, but the most interesting scree slopes and mid-slope crags are located outside the trails and are officially not accessible to tourists.

Owczarek. A little known and rather subdued basalt elevation of Owczarek (448 m) is located immediately north of the large massif of Muchowskie Wzgórza and these two may be genetically connected. In the past local basalt was exploited in three small separate quarries, now largely overgrown and poorly accessible. Regular vertical columnar jointing is exposed in the southern quarry, whereas jointing pattern in the northern quarry is irregular. Natural basalt 
outcrops are small and inconspicuous. Although the "Trail of Extinct Volcanoes" passes nearby the quarries themselves are not signposted. No particular cultural values are associated with Owczarek.

Rataj. This rather inconspicuous hill (350 m) at the marginal escarpment of the Sudetes is a remnant of a basaltic conduit, surrounded by gently rolling terrain underlain by greenschists. Eruptive history was apparently rather brief, with columnar jointing pointing out to a single phase of activity (Birkenmajer, 1967). Local basalt was intensively quarried in the $19 / 20^{\text {th }}$ century and the abandoned main quarry face exposes a perfectly developed fan-like arrangement of contraction columns (Fig. 7). The height of the quarry wall is c. $25 \mathrm{~m}$. Industrial operations partly destroyed historical relicts of an early medieval hilltop fort and nearly completely obliterated the remains of a late medieval fortress. The preserved evidence of the former includes incomplete double moat ring and associated ramparts. Rataj can be easily reached by a marked trail from the nearby village of Myślibórz, where the regional centre of ecological education is located.

Wilkolak. This is arguably the most famous volcanic outcrop in the entire south-west Poland, although rather modest in terms of altitude $(373 \mathrm{~m})$. The original shape of the hill has been considerably modified due to protracted and intensive human activity, mainly quarrying. A large working quarry is situated on the eastern side, exposing a variety of columnar jointing patterns that reflects multi-phase activity (Śliwa, 1967). Whilst it is often visited by specialist parties of geologists, general public has no access to this part of the hill. On the opposite side of the summit, in an old quarry abandoned in the early $20^{\text {th }}$ century, a geological nature reserve was set up in 1959 , with the primary aim to protect the outcrop with columnar jointing of varied geometry. Heavily overgrown for a long time and poorly exposed, the quarry walls are now much better seen after vegetation clearance took place (Fig. 8). $\mathrm{K}$-Ar dating provides an age of $20 \mathrm{Ma}$, i.e. the youngest date among basalts and related volcanic rocks in the region (Birkenmajer et al., 2007). Geological values of the locality were described by Birkenmajer (1967), Śliwa (1967) and Maciejak (2010), whereas Migon et al. (2002) emphasised the existence of thick sequences of Quaternary slope deposits of palaeoclimatic significance. Most recently, the past and present significance of Wilkołak has been comprehensively evaluated by Maciejak and Gorzkowski (2010). Nonetheless, Wilkołak lacks basic tourist infrastructure and the reserve is beyond the marked trail that skirts the summit part.

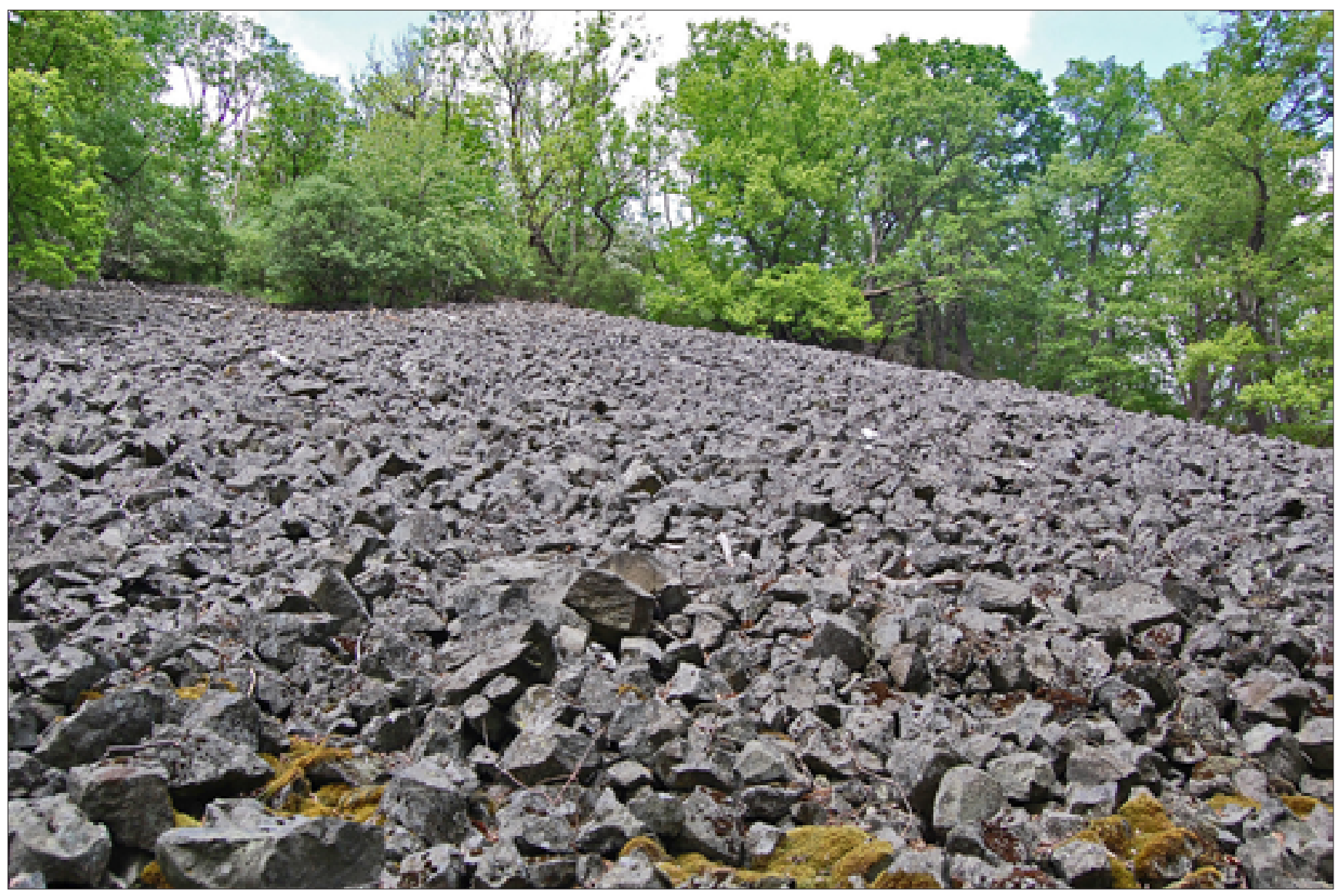

Fig. 6. Extensive bare scree slopes of Ostrzyca, supplied by mechanical disintegration of basaltic crags with well-developed columnar jointing, photo P. Migoń 


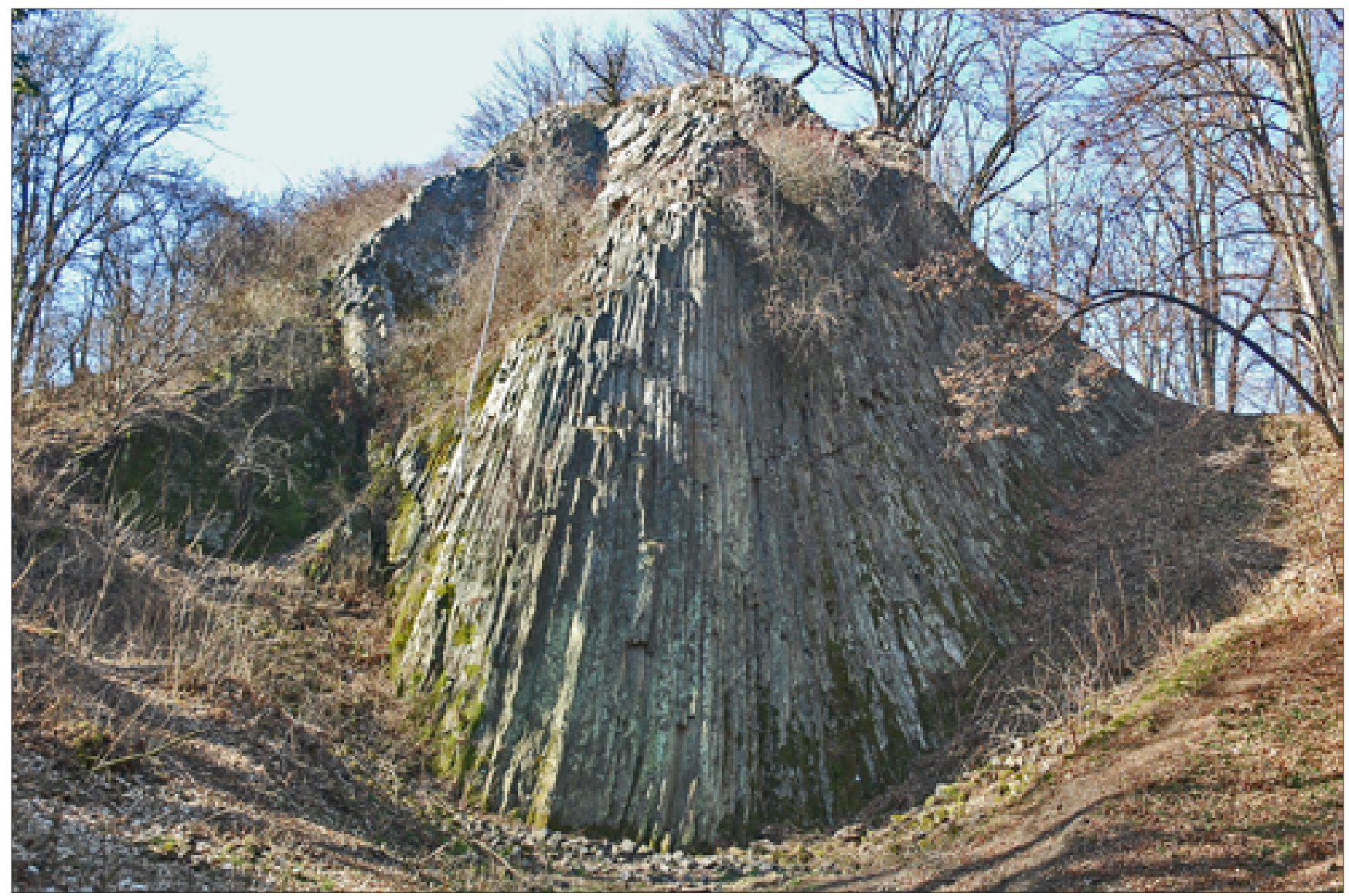

Fig. 7. Simple columnar jointing arrangement at Rataj, photo P. Migoń

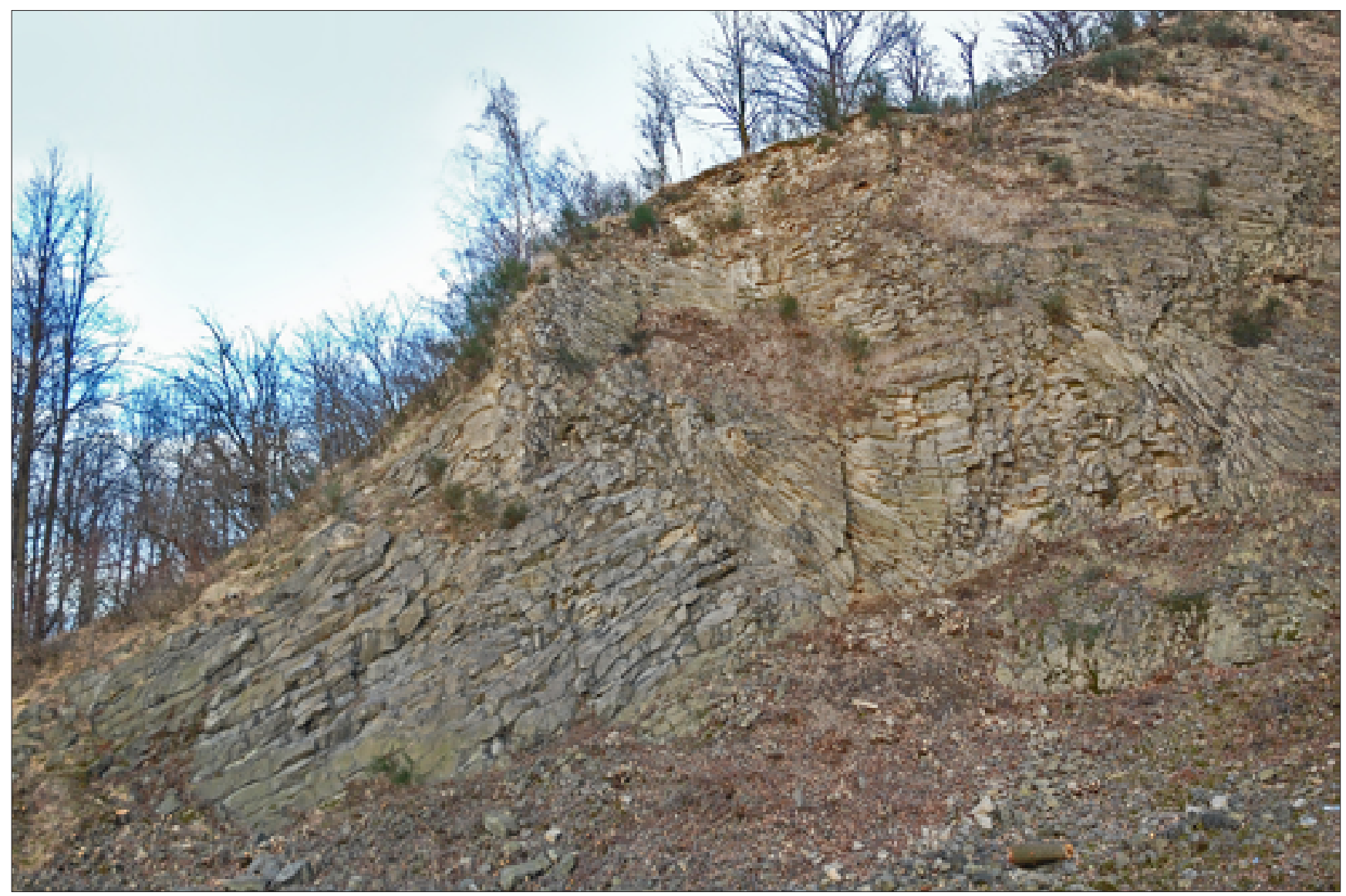

Fig. 8. Former quarry wall at Wilkołak, in Wilcza Góra nature reserve, after recent (2013) vegetation clearance, photo P. Migoń 


\section{Methods}

In this study six criteria were taken into consideration to determine attractiveness of the geosites. These components comprise scientific value, educational value, additional value, aesthetic value, accessibility and state of preservation. The evaluation process consists of three steps. In the first one selected geosites were assessed in four-point scale and ascribed a value ranging from 0 to 3 for each criterion, according to the description presented in Table 1. Geotourism attractiveness of the geosites was then expressed as the sum of points assigned to the criteria considered, which is the approach commonly presented in the literature (Pereira et al., 2007; Migoń, Sobczyk, 2009; Ihnatowicz et al., 2011).

Tab. 1. Criteria selected for the assessment of geosites in the Pogórze Kaczawskie region

\begin{tabular}{|c|c|c|}
\hline Criterion & Object characteristics & Scores \\
\hline \multirow{4}{*}{ Scientific value } & scientifically very well recognized, presented in international literature, unique in the region & 3 \\
\hline & scientifically well recognized, presented in national literature, distinctive in the region & 2 \\
\hline & mentioned in scientific literature, presented in local publications, typical for the region & 1 \\
\hline & not presented in scientific literature, no specific features & 0 \\
\hline \multirow{4}{*}{ Educational value } & more than three topics in Earth science possible to present & 3 \\
\hline & three topics in Earth science possible to present & 2 \\
\hline & one or two topics in Earth science possible to present & 1 \\
\hline & limited opportunities of geo-educational use & 0 \\
\hline \multirow{4}{*}{ Additional value } & significant object of cultural heritage or outstanding biological values (nature reserve) & 3 \\
\hline & moderately important object of cultural heritage or presence of valuable biotic elements & 2 \\
\hline & historical element of local importance & 1 \\
\hline & no significant biological, cultural or historical elements & 0 \\
\hline \multirow{4}{*}{ Aesthetic value } & high aesthetic value, outstanding element of regional landscape, very good viewpoint & 3 \\
\hline & moderate aesthetic value, distinctive element of regional landscape, viewpoint & 2 \\
\hline & minor aesthetic value, indistinct element of regional landscape & 1 \\
\hline & no specific aesthetic features & 0 \\
\hline \multirow{4}{*}{ Accessibility } & easy access - less than $100 \mathrm{~m}$ from roadway, well maintained and clearly marked & 3 \\
\hline & access through footpath in less than 20 minutes, well maintained and clearly marked & 2 \\
\hline & access through footpath in 20-60 minutes or access path poorly marked & 1 \\
\hline & constrained and unmarked access & 0 \\
\hline \multirow{4}{*}{ State of preservation } & no signs of degradation, well-exposed & 3 \\
\hline & slightly damaged, partially overgrown & 2 \\
\hline & damaged, markedly overgrown, main geological and geomorphological features poorly visible & 1 \\
\hline & devastated, entirely overgrown, main geological and geomorphological features not exposed & 0 \\
\hline
\end{tabular}


Based on the assumption that not all of these criteria are equally important for different geotourism market segments (or potential recipients of geotourism offer) an attempt to establish each criterion's relative weight was made in the second step. For this purpose three categories of visitors to geosites with different background were selected from the typology proposed by Grant (2010, cited by Dowling, 2011), i.e. geo-expert, interested visitor and unaware visitor. The importance of the criteria in the assessment process from the perspective of each of these groups was then determined in a qualitative way (Tab. 2). In order to assign numerical weight values to the six parameters considered three different rankings of the criteria were carried out, which reflect the likely priorities of the visitors. Then points ranging from 1 to 3 were assigned to each parameter depending on its rank (Tab. 3). The final weight of a given criterion in a given group of visitors was obtained by dividing the score that the criterion attained (1 to 3 ) by the number of criteria on exactly the same position in the ranking within a single group (Tab. 4). As an illustrative example, in case of an interested visitor the criterion of scientific value obtained the weight value of 0.5 according to the equation $2: 4=0.5$, where 2 is the score assigned basing on the rank (see Tab. 3) and 4 is the number of criteria of the same rank in this group (viz. scientific value, additional value, accessibility, state of preservation). Application of this procedure allowed us to maintain the identical total value being the sum of weights assigned to six criteria in each visitor group and thus ensured the comparability of the results.

Tab. 2. Importance of assessment criteria from the perspective of different groups of visitors

\begin{tabular}{|c|c|c|c|}
\hline Criteria & Geo-expert & $\begin{array}{c}\text { Interested } \\
\text { visitor }\end{array}$ & $\begin{array}{c}\text { Unaware } \\
\text { visitor }\end{array}$ \\
\hline $\begin{array}{c}\text { Scientific } \\
\text { value }\end{array}$ & significant & moderate & minor \\
\hline $\begin{array}{c}\text { Educational } \\
\text { value }\end{array}$ & moderate & significant & moderate \\
\hline $\begin{array}{c}\text { Additional } \\
\text { value }\end{array}$ & minor & moderate & moderate \\
\hline $\begin{array}{c}\text { Aesthetic } \\
\text { value }\end{array}$ & minor & minor & significant \\
\hline $\begin{array}{c}\text { Accessibility } \\
\text { State of } \\
\text { preservation }\end{array}$ & moderate & moderate & moderate \\
\hline
\end{tabular}

Tab. 4. The final weights of criteria

\begin{tabular}{|c|c|c|c|}
\multirow{2}{*}{ Criteria } & \multicolumn{3}{|c|}{ Weights } \\
\cline { 2 - 4 } & geo-expert & $\begin{array}{c}\text { interested } \\
\text { visitor }\end{array}$ & $\begin{array}{c}\text { unaware } \\
\text { visitor }\end{array}$ \\
\hline $\begin{array}{c}\text { Scientific value } \\
\text { Educational } \\
\text { value }\end{array}$ & 1 & 0.5 & 1 \\
\hline $\begin{array}{c}\text { Additional } \\
\text { value }\end{array}$ & $0 .(3)$ & 0.5 & $0 .(6)$ \\
\hline $\begin{array}{c}\text { Aesthetic } \\
\text { value }\end{array}$ & $0 .(3)$ & 1 & 1.5 \\
\hline $\begin{array}{c}\text { Accessibility } \\
\text { State of } \\
\text { preservation }\end{array}$ & $0 .(3)$ & 0.5 & 1.5 \\
\hline $\begin{array}{c}\text { Sum of } \\
\text { weights }\end{array}$ & 6 & 6 & $0 .(6)$ \\
\hline
\end{tabular}

Tab. 3. Anticipated rankings of evaluation criteria applicable to different groups of visitors, with scores assigned

\begin{tabular}{|c|c|c|c|c|c|c|}
\hline \multirow{2}{*}{ Rank } & \multicolumn{6}{|c|}{ Criteria and scores } \\
\hline & geo-expert & scores & interested visitor & scores & unaware visitor & scores \\
\hline 1 & Scientific value & 3 & Educational value & 3 & $\begin{array}{c}\text { Aesthetic value } \\
\text { Accessibility }\end{array}$ & $\begin{array}{l}3 \\
3\end{array}$ \\
\hline 2 & $\begin{array}{l}\text { Educational value } \\
\text { State of preservation }\end{array}$ & $\begin{array}{l}2 \\
2\end{array}$ & $\begin{array}{c}\text { Scientific value } \\
\text { Additional value } \\
\text { Accessibility } \\
\text { State of preservation }\end{array}$ & $\begin{array}{l}2 \\
2 \\
2 \\
2\end{array}$ & $\begin{array}{l}\text { Educational value } \\
\text { Additional value } \\
\text { State of preservation }\end{array}$ & $\begin{array}{l}2 \\
2 \\
2\end{array}$ \\
\hline 3 & $\begin{array}{c}\text { Additional value } \\
\text { Aesthetic value } \\
\text { Accessibility }\end{array}$ & $\begin{array}{l}1 \\
1 \\
1\end{array}$ & Aesthetic value & 1 & Scientific value & 1 \\
\hline
\end{tabular}


In the last step in this evaluation method the values obtained by geosites for each parameter in the very first general assessment (step one) were multiplied by the calculated weights (step two) and finally added up, for each group of visitors separately.

\section{Results}

The final results of numerical geosite assessment are summarized in Table 5. General evaluation highlights Ostrzyca as the most attractive geosite that scored the maximum number of points in three out of four categories pertinent to intrinsic values of the spot. It is followed by Wilkołak, which is the best site to appreciate volcanic legacy but is less endowed in other values and accessibility is limited. Two sites share the third position but apparently for different reasons. Whereas good performance of Rataj is due to its excellent state of preservation and exposure of columnar jointing that has considerable educational value (after recent clearing), Grodziec scores high because of its added value (medieval castle) and easy access. Results of the evaluation are reasonably consistent with the work by Cedro et al. (2009), in which Wilkołak was on top of the list, followed by Ostrzyca and Grodziec, sharing the same number of evaluation points. Czartowska Skała occupied the fourth position whilst its performance was poorer in the evaluation presented here (no. 6-7). However, it must be noted that Cedro et al. (2009) used partly different criteria and a five-point scale.

In the next step, the assessment procedure was re-evaluated considering three different groups of visitors and their likely preferences. Different scores obtained by a given geosite give us information which category of visitors value it most and from whose perspective it is least attractive. It is worth to notice that in no case a single geosite is equally attractive for two or three different segments of geotourism market. This finding highlights how subjective the evaluation process and the perception of geosite attractiveness might be if differentiation of visitors concerning their background and motivation is not taken into account.

Based on the final scores obtained by geosites in the initial, general evaluation and ones derived from the modified approach, four rankings were prepared for comparison of results (Tab. 6). Although the degree of coincidence between the rankings are relatively high, which is supported by high values of Spearman's correlation coefficient (Tab. 7) (Bruschi, Cendrero, 2011), it is easily seen that the ranks obtained by some geosites differ considerably. This is the case of Grodziec, Muchowskie Wzgórza and Diablak for which maximum differences of 7, 6 and 5 positions respectively are reached when comparing different rankings. The agreement, on the other hand, is best for geosites in the top (Ostrzyca) and the bottom positions (Górzec and Owczarek), where the differences never exceed one position.

Tab. 5. Numerical assessment of selected geosites in the Pogórze Kaczawskie region

\begin{tabular}{|c|c|c|c|c|c|c|c|c|c|c|}
\hline \multirow[b]{2}{*}{ Geosite } & \multicolumn{7}{|c|}{ General evaluation } & \multicolumn{3}{|c|}{$\begin{array}{l}\text { Customer-oriented evalua- } \\
\text { tions (only total scores given) }\end{array}$} \\
\hline & 䢘 & 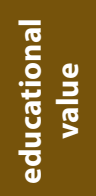 & 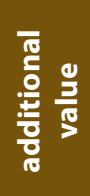 & 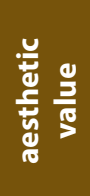 & 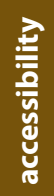 & 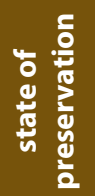 & 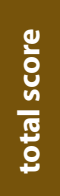 & 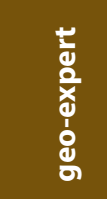 & 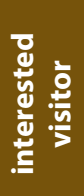 & 产 \\
\hline Bazaltowa & 1 & 2 & 1 & 1 & 2 & 2 & 9 & 8.3 & 10.0 & 8.8 \\
\hline Czartowska Skała & 1 & 2 & 0 & 2 & 1 & 3 & 9 & 9.0 & 10.5 & 8.8 \\
\hline Diablak & 2 & 2 & 0 & 1 & 1 & 2 & 8 & 10.7 & 9.5 & 7.7 \\
\hline Górzec & 1 & 1 & 1 & 2 & 1 & 1 & 7 & 6.3 & 7.0 & 7.5 \\
\hline Grodziec & 1 & 1 & 3 & 2 & 3 & 1 & 11 & 7.7 & 9.0 & 11.8 \\
\hline Krzyżowa Góra & 1 & 2 & 0 & 0 & 3 & 2 & 8 & 8.0 & 9.0 & 8.2 \\
\hline Muchowskie Wzgórza & 2 & 1 & 1 & 1 & 1 & 3 & 10 & 11.0 & 7.5 & 8.3 \\
\hline Ostrzyca & 2 & 3 & 3 & 3 & 1 & 3 & 15 & 14.3 & 16.5 & 14.0 \\
\hline Owczarek & 1 & 1 & 0 & 0 & 2 & 2 & 6 & 6.7 & 5.5 & 6.0 \\
\hline Rataj & 1 & 2 & 2 & 1 & 2 & 3 & 11 & 9.7 & 11.0 & 10.2 \\
\hline Wilkołak & 3 & 3 & 1 & 2 & 1 & 2 & 12 & 15.3 & 14.5 & 11.5 \\
\hline
\end{tabular}


Tab. 6. Rankings of geosites according to general evaluation and modified visitor-oriented approach

\begin{tabular}{|c|c|c|c|c|c|c|c|}
\hline General evaluation & Rank & Geo-expert & Rank & Interested visitor & Rank & Unaware visitor & Rank \\
\hline Ostrzyca & 1 & Wilkołak & 1 & Ostrzyca & 1 & Ostrzyca & 1 \\
\hline Wilkołak & 2 & Ostrzyca & 2 & Wilkołak & 2 & Grodziec & 2 \\
\hline Rataj & \multirow{2}{*}{ 3-4 } & Muchowskie Wzgórza & 3 & Rataj & 3 & Wilkołak & 3 \\
\hline Grodziec & & Diablak & 4 & Czartowska Skała & 4 & Rataj & 4 \\
\hline Muchowskie Wzgórza & 5 & Rataj & 5 & Bazaltowa & 5 & Bazaltowa & \multirow{2}{*}{$5-6$} \\
\hline Bazaltowa & \multirow{2}{*}{$6-7$} & Czartowska Skała & 6 & Diablak & 6 & Czartowska Skała & \\
\hline Czartowska Skała & & Bazaltowa & 7 & Krzyżowa Góra & \multirow{2}{*}{$7-9$} & Muchowskie Wzgórza & 7 \\
\hline Krzyżowa Góra & \multirow{2}{*}{$8-9$} & Krzyżowa Góra & 8 & Grodziec & & Krzyżowa Góra & 8 \\
\hline Diablak & & Grodziec & 9 & Muchowskie Wzgórza & 9 & Diablak & 9 \\
\hline Górzec & 10 & Owczarek & 10 & Górzec & 10 & Górzec & 10 \\
\hline Owczarek & 11 & Górzec & 11 & Owczarek & 11 & Owczarek & 11 \\
\hline
\end{tabular}

Coloured shading indicates geosites whose position in the rankings changed most.

Tab. 7. Coincidence between rankings expressed by Spearman's correlation coefficient

\begin{tabular}{|c|c|c|c|c|}
\hline & General evaluation & Geo-expert & Interested visitor & Unaware visitor \\
\hline General evaluation & 1 & $\mathrm{x}$ & $\mathrm{x}$ & $\mathrm{x}$ \\
\hline Geo-expert & 0.72 & 1 & 1 & $\mathrm{x}$ \\
\hline Interested visitor & 0.73 & 0.66 & 0.70 & 1 \\
\hline Unaware visitor & 0.95 & 0.54 & \\
\hline
\end{tabular}

All values are statistically significant for $p$-value $<0.10$.

The highest difference between individual evaluations for Grodziec is explained by its accessibility and considerable cultural value appreciated by non-specialists (castle, with museum, restaurant, open-air events etc.), whereas features that matter most for experts such as extensive outcrops of volcanic structures are missing. Muchowskie Wzgórza may be highly appealing to experts due to the variety of geo-phenomena (columnar jointing of different types, periglacial morphology, debate about the origin of this largest basalt occurrence in the region), but lack additional cultural values except a rather unimpressive old viewing tower and do not offer wide vistas due to dense forest. Likewise, columnar jointing in sandstone xenoliths at Diablak is an important feature for experts but is less evident to casual visitors who may look for more obvious features of interest. In addition, access to Diablak is not very convenient which would not be a problem for a keen geo-expert, but may decrease the attractiveness of the site for other groups of visitors. Different positions of Wilkołak in rankings are not so evident, but nevertheless notable. Wilkołak performs well in geo-expert classification (highest score), whereas it is considerably behind the most valued site in unaware visitor classification $\left(3^{\text {rd }}\right.$ position). This is despite its key volcanological features, which are however not supplemented by equally high other values.

\section{The role of season in appreciation and evaluation of geosites}

Seasonal aspect is an overlooked factor in evaluation procedures applied to geosites. Whilst it may not be relevant in dry areas or mountain terrains above the tree line, where vegetation hardly interferes with the visibility of geosites, it becomes crucial in densely vegetated, low-altitude terrains in temperate climate. Vegetation, especially in summer period, may adversely affect an appeal of a geosite to a visitor in 
several ways. First, geological outcrops may be hidden behind dense bush and tall grass and therefore, be hard to see. Second, the same dense plant cover may restrict physical access to the very exposure, not allowing visitors to inspect geological details. Third, well-grown vegetation around an outcrop or a small landform makes appreciation of a wider context difficult and hence, visitors cannot relate a geosite to its surrounding. Fourth, the scenic values of panoramic vantage points, which are crucial for landscape interpretation, may be significantly reduced. Fifth, certain types of vegetation may decrease safety conditions at a site, obscuring unstable ground.

Geosites related to Cenozoic volcanism in the Pogórze Kaczawskie region provide good examples to emphasize this issue (Fig. 9). Several sites are located in disused quarries which are typically subject to spontaneous re-vegetation, with birch and hawthorn (Crataegus L.) as the main expansive species. Consequently, while the patterns of columnar jointing at Bazaltowa and Czartowska Skała can be well appreciated in early spring or late autumn, in summer they become partly or entirely obscured (Fig. 9, B, C). At Ostrzyca and Muchowskie Wzgórza, none extensively quarried in the past, semi-natural forest vegetation is present and while it adds to natural values of the sites, it hides details of both rock structure exposed in outcrops and inherited periglacial slope morphology (Fig. 9, A). Development of forest undergrowth on scree slopes may hide them from view in the summer period, as on Mt Górzec. A minor, but important factor for keen geotourists is sufficient exposure of a geosite to allow taking a good photograph. Shadows from tree canopies are then considered a nuisance.

For all the above reasons, the factor of vegetation should be considered in specific circumstances of geosite evaluation. However, its evaluation is inevitably highly subjective. It might be assumed that it matters most for casual visitors whose experience, given limited background and incentive, needs to be particularly enriched by good visibility of a site of interest. Expert visitors with strong motivation are less likely to be seriously affected, but this is an educated guess only. Notwithstanding subjectivity, an attempt is made to include this factor in the evaluation. The procedure consists of the following steps. First, geosites are classified according to the degree of reduction of their visual appeal, considered as 'significant', 'moderate' or 'minor' (Tab. 8). Second, an arbitrary value of a 'correcting factor' is established which varies from 0.25 (significant reduction) to 0.75 (minor reduction). Third, numerical scores obtained by educational and aesthetic values (Tab. 1) are multiplied by the 'correcting factor' and the revised scores are summed. This step is based on the assumption that scientific and added values as well as access, understood here as the distance from a road/parking and the presence/absence of a well-signposted trail (see Tab. 1, criterion no. 5), are not sensitive to the presence of vegetation cover at the geosite itself, whereas state of preservation already includes evaluation of site visibility.

Tab. 8. Reduction of geosite visual appeal with the values of 'correcting factor'

\begin{tabular}{|c|c|c|c|}
\hline Geosite & Vegetation & Reduction of geosite appeal & Correcting factor \\
\hline Bazaltowa & $\begin{array}{l}\text { trees in spontaneous } \\
\text { succession in a quarry }\end{array}$ & significant & 0.25 \\
\hline Rataj & $\begin{array}{l}\text { forest. but recent veg- } \\
\text { etation clearance }\end{array}$ & minor & 0.75 \\
\hline Górzec & semi-natural forest & significant & 0.25 \\
\hline Krzyżowa Góra & bushes. grass & minor & 0.75 \\
\hline Muchowskie Wzgórza & semi-natural forest & moderate & 0.5 \\
\hline Owczarek & semi-natural forest & moderate & 0.5 \\
\hline Czartowska Skała & bushes. occasional trees & moderate & 0.5 \\
\hline Diablak & semi-natural forest & moderate & 0.5 \\
\hline Wilkołak & $\begin{array}{l}\text { low tress. bushes. grass. with } \\
\text { recent vegetation clearance }\end{array}$ & minor & 0.75 \\
\hline Ostrzyca & semi-natural forest & moderate & 0.5 \\
\hline Grodziec* & semi-natural forest & minor & 0.75 \\
\hline
\end{tabular}

* The main value of Grodziec consists of its appearance from the distance. 
A1)

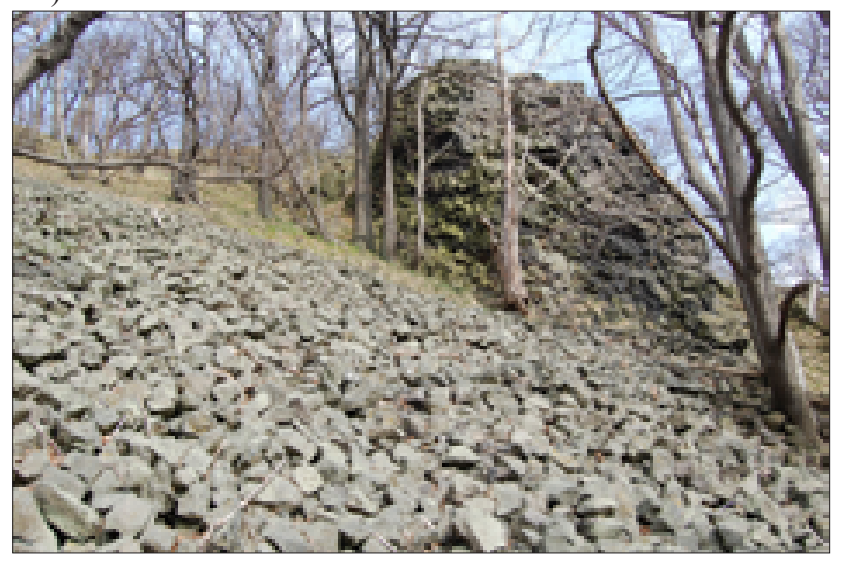

B1)

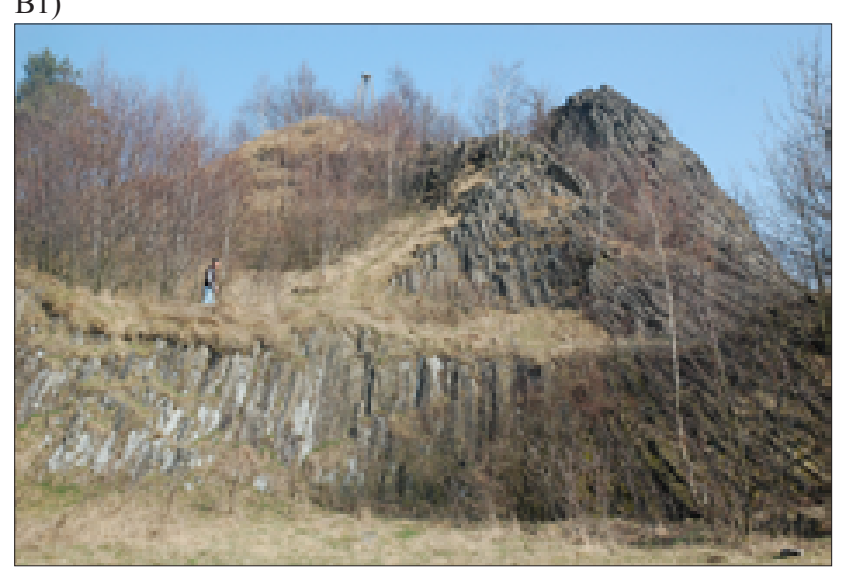

C1)

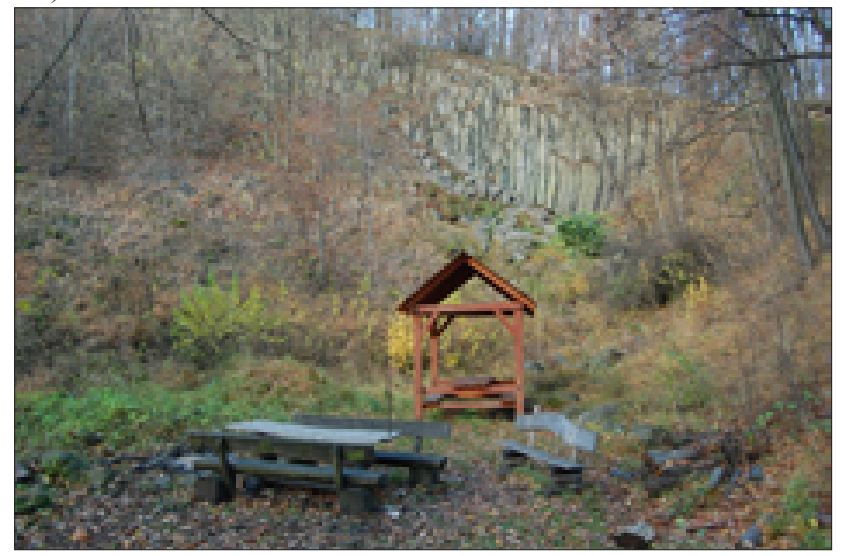

D1)

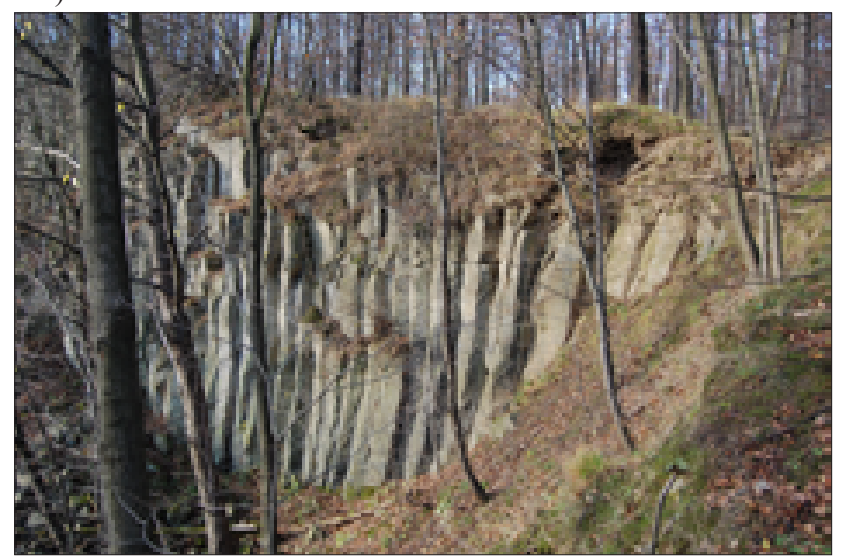

A2)

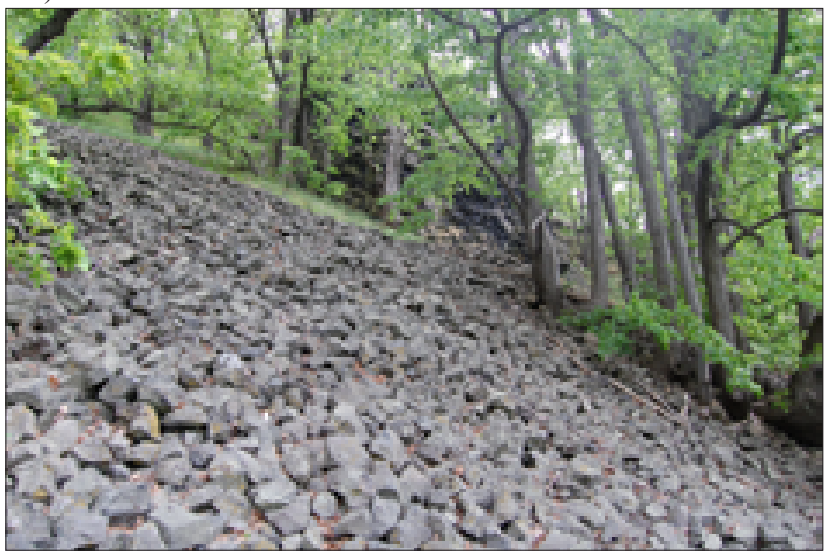

B2)

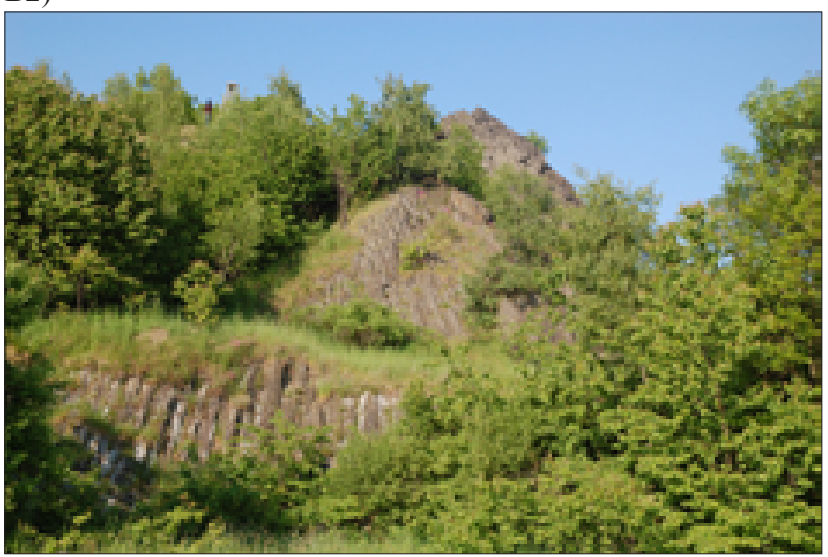

C2)

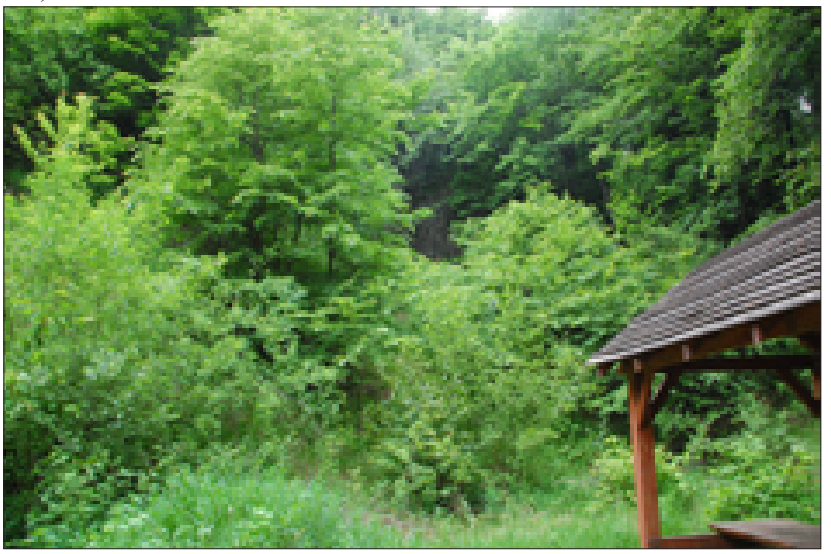

D2)

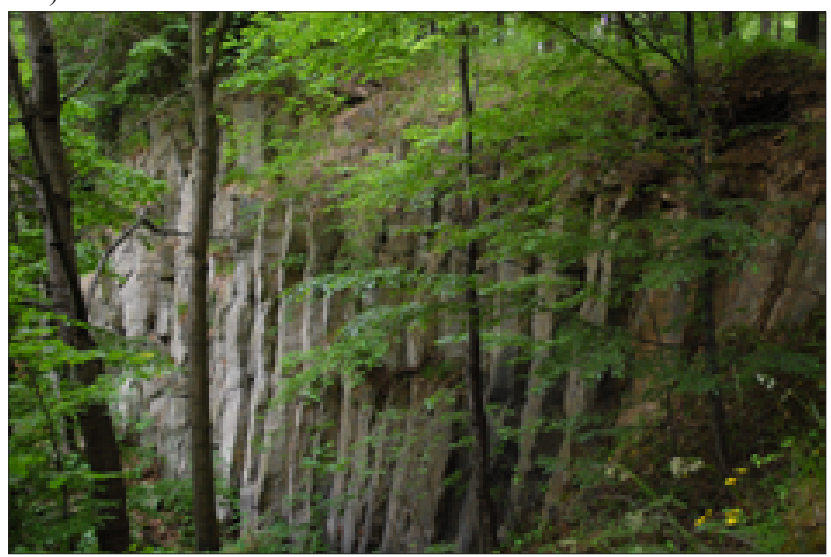

Fig. 9. The influence of vegetation cover on the visibility of volcanic geosites (1 - early spring/late autumn, 2 - summer), all photos P. Migoń. A - crags and scree slopes at Ostrzyca; B - Czartowska Skała; C - Bazaltowa: general view of the quarry; D - Bazaltowa: closeup of the quarry wall 


\begin{tabular}{|c|c|c|c|c|c|c|c|c|c|c|c|c|c|}
\hline \multirow{3}{*}{ 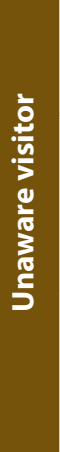 } & 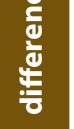 & $\stackrel{n ?}{T}$ & $\stackrel{\sim}{i}$ & 0 & $T$ & - & $m$ & - & T & - & 0 & 0 & \&̊. \\
\hline & 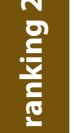 & $\wedge$ & $\infty$ & $a$ & $=$ & - & in & 0 & $\sim$ & $\stackrel{\circ}{-}$ & $\sigma$ & $m$ & \\
\hline & 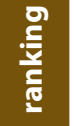 & $\stackrel{n}{n}$ & นn & $a$ & $\stackrel{\circ}{-}$ & $\sim$ & $\infty$ & $\wedge$ & - & $\mp$ & $\sigma$ & $m$ & \\
\hline \multirow{3}{*}{ 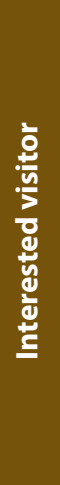 } & 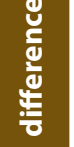 & † & $\uparrow$ & $T$ & $T$ & $\stackrel{\operatorname{Ln}}{m}$ & $\stackrel{\operatorname{nn}}{N}$ & - & $T$ & - & 0 & - & $\begin{array}{l}\infty \\
\stackrel{\infty}{0} \\
0\end{array}$ \\
\hline & 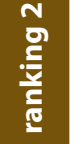 & $a$ & 0 & $\wedge$ & $=$ & $\nabla$ & in & $\infty$ & $\sim$ & $\stackrel{\circ}{-}$ & $m$ & - & \\
\hline & 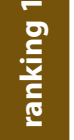 & in & $\nabla$ & 0 & $\stackrel{\circ}{\circ}$ & $\stackrel{n}{N}$ & $\stackrel{\operatorname{Ln}}{\wedge}$ & $a$ & - & $=$ & $m$ & $\sim$ & \\
\hline \multirow{3}{*}{$\begin{array}{l}\text { ț } \\
\frac{0}{0} \\
\frac{0}{0} \\
0 \\
0 \\
\mathrm{~d}\end{array}$} & 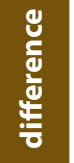 & $\Upsilon$ & 0 & 0 & 0 & - & - & 0 & 0 & 0 & 0 & 0 & ă \\
\hline & 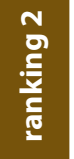 & $a$ & 0 & $\sigma$ & $=$ & $\infty$ & $\wedge$ & $m$ & $\sim$ & $\circ$ & in & - & \\
\hline & 홀 & $\wedge$ & 0 & $\nabla$ & $=$ & $a$ & $\infty$ & $m$ & $N$ & $\stackrel{\circ}{\circ}$ & in & - & \\
\hline \multirow{3}{*}{ 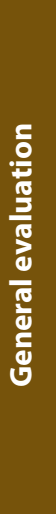 } & 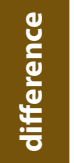 & $\stackrel{n ?}{T}$ & nn & 吕 & $T$ & 0 & $\stackrel{\operatorname{Ln}}{N}$ & 0 & 0 & - & 0 & 0 & 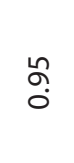 \\
\hline & 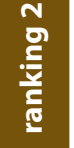 & $\infty$ & $\wedge$ & $a$ & $=$ & $\stackrel{\operatorname{nn}}{m}$ & 0 & in & - & $\stackrel{\circ}{\circ}$ & $\stackrel{\mathscr{n}}{m}$ & $\sim$ & \\
\hline & 홀 & $\stackrel{n}{0}$ & 虫 & $\begin{array}{l}L_{\infty}^{\infty} \\
\infty\end{array}$ & $\stackrel{\circ}{\circ}$ & $\stackrel{\sim}{m}$ & $\begin{array}{l}\stackrel{L}{\infty} \\
\infty\end{array}$ & in & - & $=$ & $\stackrel{\mu n}{m}$ & $\sim$ & \\
\hline$£$ & & 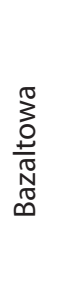 & 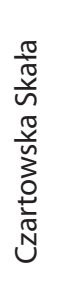 & $\begin{array}{l}\frac{\frac{r}{0}}{\frac{0}{0}} \\
\frac{\sigma \pi}{0}\end{array}$ & 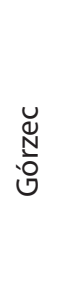 & $\begin{array}{l}\frac{\breve{U}}{N} \\
\frac{0}{0} \\
\frac{0}{v}\end{array}$ & 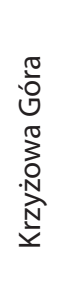 & 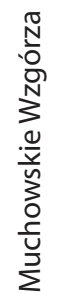 & 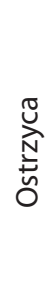 & 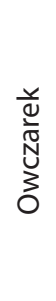 & 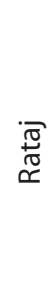 & $\begin{array}{l}\frac{\frac{2}{0}}{\frac{0}{0}} \\
\frac{2}{3} \\
\frac{3}{3}\end{array}$ & 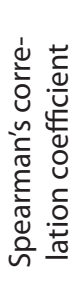 \\
\hline
\end{tabular}


Differences in positions obtained by geosites in both rankings are presented in Table 9. The highest degree of coincidence among four pairs of rankings typifies geo-expert approach for whom re-evaluated educational and aesthetic values are assumed not to be particularly important components in their own assessment of geosite attractiveness (Tab. 2). It is worth to emphasize that in eight cases no change in the rank of an object is observed. By comparison, nearly all geosites change their positions when a new ranking for interested visitor is considered. This is explained by the fact that it was values of criteria with the highest weights for this category of visitors that were subjected to reduction. These differences are reflected by the lowest value of Spearman's correlation coefficient (0.80). It must be however admitted that the degree of coincidence between the two rankings is still relatively high. Nevertheless, the rank of at least two geosites (Bazaltowa and Grodziec) evidently changed comparing to the others. In fact, these are the most profound shifts of position in all rankings.

Multiplication of educational and aesthetic values of geosites by the lowest 'correcting factor' value of 0.25 , corresponding to their significant reduction due to uncontrolled vegetation growth, impaired the position of geosites in all cases, with the exception of Górzec geosite in the expert's ranking, in which no change in the rank occurred. When geosites with the highest 'correcting factor' value of 0.75 (i.e. minor reduction) are considered, the application of introduced procedure may elevate the position of a geosite (Krzyżowa, Grodziec) or it may have no influence on its rank (Rataj, Wilkołak), depending on the position in the 'uncorrected' ranking.

Finally it needs to be emphasized that the vegetation factor is easily modified by people (intended site clearance driven by geoconservation motivations or intentions to enhance tourist attractiveness). In the last few years major clearances were undertaken at Wilkołak and Rataj - two most scenic outcrops of columnar jointing - and the scenic qualities of both sites have been considerably improved. Otherwise, both would have been characterized by very low $(0.25)$ values of the correcting factor.

\section{Concluding remarks}

Application of the new approach introduced in this paper emphasizes the problem of subjectivity, frequently mentioned in the literature focused on quantitative assessment of geosites (Bruschi, Cendrero, 2005; Pereira, Pereira, 2010; Coratza, Bruschi, 2011; Kubalíková, 2013). As it was shown, individual preferences and needs of visitors with different backgrounds, anticipated not to be similar, may affect the final result of the evaluation. Although generally a high degree of coincidence between presented rankings was obtained (Tab. 7), attractiveness of specific geosites may be perceived in a markedly different way. If so, perception of attractiveness of an object should be considered in the light of particular values that different categories of visitors likely appreciate most.
When the results obtained from the general evaluation are compared with the ones derived from the modified approach (Tab. 7), it may be surprising that the highest degree of coincidence occurs between general evaluation and the evaluation corresponding to unaware visitor, not to geo-expert. This result is counterintuitive in the sense that geosite assessment is the task undertaken predominantly by people with considerable knowledge in Earth science. Based on this fact we might anticipate that the initial, non-weighted evaluation would be most similar to the one corresponding to geo-expert. The reason behind this divergence lies in the mathematical division of the weights for each criterion considered, in which the sum of weights has an unchangeable value of 6 (Tab. 4). Having only one 'dominant' criterion with the weight of 3 in the cases of geo-expert (scientific value) and interested visitor (educational value) and two 'dominant' in case of unaware visitor (aesthetic value and accessibility) with the weights of 1.5 each, changes in numerical values obtained by geosites after re-evaluation should presumably be least in the latter case. In this case the highest weight value of 3, which may significantly modify the rank of a geosite, especially when a high initial value of a criterion is multiplied, is split into two components. The probability of change of geosite position in a ranking is therefore lower and the degree of coincidence between initial ranking and the one obtained after re-evaluation remains high.

Sensitivity of evaluation procedure to the vegetation factor, introduced as a modifying component, proved less evident than expected. Only a few geosites have markedly changed their rank whilst the majority remained in the same position or shifts were minor. This approach to geosite assessment has problems of its own. Considering vegetation as a disturbing factor goes against a recommended, more holistic view of geosites and underlines the gap between abiotic and biotic factors. On the other hand, it may be useful while planning a schedule of geo-educational outdoor activities within a year.

The approach to geosite assessment introduced here, which should be treated as an attempt to make this process more customer-oriented, needs to be applied to a higher number of geosites in the future. In our pilot study only eleven geosites were considered, in order to remain within one thematic area (Cenozoic volcanism). Likewise, it should be emphasized that a method developed to include the role of season in the appreciation and evaluation of geosites is by no means considered a final proposal. To the contrary, it is only an introduction to the problem which seems overlooked. Both the classification of vegetation impact into 'significant', 'moderate' and 'minor' is subjective, as well as the corresponding values of 'correcting factor' were arbitrarily chosen. Further research is recommended, including an extension of the number of geosites subject to this sort of exercise.

\section{Acknowledgements}

We extend our thanks to Ewelina and Krzysztof Rozpędowscy for their sustained support of our studies of geoheritage and geotourism in the 'Land of Extinct Volcanoes' region. We also acknowledge Kacper Jancewicz for preparing Figure 1. 


\section{References}

Anioł-Kwiatkowska J., Świerkosz K., 1992. Flora i roślinność rezerwatu Ostrzyca Proboszczowicka oraz jego otoczenia. Acta Universitatis Wratislaviensis, Prace Botaniczne, 48: 45-115.

Badura J., Pécskay Z., Koszowska E., WolskaA., Zuchiewicz W., Przybylski B., 2005. New age and petrological constraints on Lower Silesian basaltoids, SW Poland. Acta Geodynamica et Geomaterialia, 2, 3(139): 7-15.

Baraniecki L., 1952. Gołoborza Ostrzycy i Sobótki. Czasopismo Geograficzne, 21/22: 439-440.

Birkenmajer K., 1967. Bazalty dolnośląskie jako zabytki przyrody nieożywionej. Ochrona Przyrody, 32: 225-276.

Birkenmajer K., Pécskay Z., Grabowski J., Lorenc M.W., Zagożdżon P., 2007. Radiometric dating of the Tertiary volcanics in Lower Silesia, Poland. V. K-Ar and palaeomagnetic data from Late Oligocene to Early Miocene basaltic rocks of the North-Sudetic Depression. Annales Societatis Geologorum Poloniae, 77: 1-16.

Bogdański J., 2004. Geologiczny raj Krainy Wygasłych Wulkanów. Stowarzyszenie Kaczawskie, Mściwojów.

Božić S., Tomić N., Palić, D., 2014. Canyons as a potential geotourism attractions of Serbia - comparative analysis of Lazar and Uvac canyons by using M-GAM model. Acta Geoturistica, 5: 18-30.

Bruschi V. M., Cendrero A., 2005. Geosite evaluation; can we measure intangible values? Il Quaternario, 18: 293-306.

Bruschi V.M., Cendrero A., Cuesta Albertos J.A., 2011. A Statistical Approach to the Validation and Optimisation of Geoheritage Assessment Procedures. Geoheritage, 3: 131-149.

Cedro B., Mianowicz K., Zawadzki D., 2009. Ocena walorów geoturystycznych stanowisk pochodzenia wulkanicznego Gór i Pogórza Kaczawskiego. Problemy Turystyki i Rekreacji, 2: 25-35.

Coratza P., Bruschi V.M., 2011. Recognition and Assessment of Geomorphosites in Malta at the Il-Majjistral Nature and History Park. Geoheritage, 3: 175-185.

Coratza P., Giusti C., 2005. Methodological proposal for the assessment of the scientific quality of geomorphosites. Il Quaternario, 18: 307-313.

Coratza P., Galve J.P., Soldati M., Tonelli C., 2012. Recognition and assessment of sinkholes as geosites: lessons from the Island of Gozo (Malta) Quaestiones Geographicae, 31: 25-35.

Dowling R.K., 2011. Geotourism's global growth. Geoheritage, 3: 1-13.

Dylikowa A., 1952. Wycieczka w Góry Kaczawskie. Geografia w Szkole, 3(2): $26-42$

Feuillet T., Sourp E., 2011. Geomorphological Heritage of the Pyrenees National Park (France): Assessment, Clustering and Promotion of Geomorphosites. Geoheritage, 3: 151-162.

Grant C., 2010. Towards a typology of visitors to geosites. Paper presented at the Second Global Geotourism Conference, Making Unique Landforms Understandable. Mulu, Sarawak, Malaysia, 17-20 April.

Grocholski W. (ed.), 1967. Przewodnik geologiczny po Sudetach. Wydawnictwa Geologiczne, Warszawa.

Grocholski A., Jerzmański J., 1975. Zabytki paleowulkanizmu na Dolnym Śląsku w świetle ochrony przyrody. Ochrona Przyrody, 40: 291-340.

Grocholski A., Wiśniewski E., 1995. Przewodnik geologiczny po Parku Krajobrazowym Chetmy na Pogórzu Kaczawskim. Państwowy Instytut Geologiczny, Wrocław.

Hurtado H., Dowling R., Anders D., 2013. An exploratory Study to Develop a Geotourism Typology Model. International Journal of Tourism Research, 16: 605-608.

Ihnatowicz A., Koźma J., Wajsprych B., 2011. Wałbrzyski Obszar Geoturystyczny - inwentaryzacja geotopów dla potrzeb promocji geoturystyki. Przegląd Geologiczny, 59: 722-731.

Kryza R., 2008. The Variscan Kaczawa Complex: witness of Palaeozoic basins and Variscan orogeny. In: Solecki A. (ed.), Geoeducational Potential of the Sudety Mts., University of Wrocław, Institute of Geological Sciences, Wrocław: 53-63.
Kubalíková L., 2013. Geomorphosite assessment for geotourism purposes. Czech Journal of Tourism, 2: 80-104. DOI: 10.2478/cjot-2013-0005.

Lima F.F., Brilha J.B., Salamuni E., 2010. Inventorying Geological Heritage in Large Territories: A Methodological Proposal Applied to Brasil. Geoheritage, 2: 91-99.

Maciejak K., 2010. Wilkołak jako element środkowoeuropejskiej prowincji wulkanicznej. In: Gorzkowski R. (ed.), Wilkołak (Wilcza Góra) koło Złotoryi. Geologia - przyroda - historia, Towarzystwo Miłośników Ziemi Złotoryjskiej, Złotoryja, 11-42.

Maciejak K., Gorzkowski R., 2010. Rezerwat przyrody Wilcza Góra i jego rola w edukacji przyrodniczej i regionalnej. In: Gorzkowski R. (ed.), Wilkołak (Wilcza Góra) koło Złotoryi. Geologia - przyroda-historia, Towarzystwo Miłośników Ziemi Złotoryjskiej, Złotoryja, 135-165.

Maciejak K., Maciejak K., 2006. Na tropach dawnego górnictwa Gór i Pogórza Kaczawskiego, GoldCentrum, Złotoryja.

Migoń P., 2014. Atrakcje geoturystyczne krainy wygastych wulkanów. Stowarzyszenie „Lokalna Grupa Działania Partnerstwo Kaczawskie”, Mściwojów.

Migoń P., Pijet-Migoń E., 2010. Problemy udostępniania turystycznego obiektów wulkanicznego dziedzictwa Ziemi na przykładzie Pogórza Kaczawskiego. Zeszyty Naukowe Wyższej Szkoly Bankowej we Wrocławiu, 17: 129-151.

Migoń P., Maciejak K., Zygmunt M., 2002. Peryglacjalna rzeźba wzgórz bazaltowych Pogórza Kaczawskiego (Sudety Zachodnie) i jej znaczenie dla paleogeografii plejstocenu. Przeglad Geograficzny, 74: 491-508.

Migoń P., Sobczyk A., 2009. Opracowanie metodyki waloryzacji i waloryzacja geostanowisk Karkonoskiego Parku Narodowego i jego otuliny. In: Knapik R., Jała Z., Sobczyk A., Migoń P., Aleksandrowski P., Szuszkiewicz A., Krąpiec M., Madej S., Krakowski K., Inwentaryzacja $i$ waloryzacja geostanowisk Karkonoskiego Parku Narodowego i jego otuliny oraz wykonanie mapy geologicznej tego obszaru, Karkonoski Park Narodowy, Jelenia Góra, 5-16.

Pereira P., Pereira D., 2010. Methodological guidelines for geomorphosite assessment. Géomorphologie: relief, processus, environnement, 2: 215-222.

Pereira P., Pereira D., Caetano Alves M.I., 2007. Geomorphosite assessment in Montesinho Natural Park (Portugal). Geographica Helvetica, 62: 159-168.

Pijet-Migoń E., Migoń P., 2009. Projekt „W krainie wygasłych wulkanów” szansą dla rozwoju turystyki zrównoważonej na Pogórzu Kaczawskim. In: Rola turystyki w gospodarce regionów, vol. II, Wyższa Szkoła Handlowa we Wrocławiu, Wrocław, 338-345.

Placek A., 2007. Basaltic hills as structural landforms - morphometry versus rock strength (a study from the Kaczawskie upland, SW Poland). Universitatis Ostravensis Acta Facultatis Rerum Naturalium, 237, Geographia - Geologia, 10: 111-127.

Reynard E., Fontana G., Kozlik L., Scapozza C., 2007. A method for assessing scientific and additional values of geomorphosites. Geographica Helvetica, 62: 148-158.

Rybár P., 2010. Assessment of attractiveness (value) of geotouristic objects. Acta Geoturistica, 1: 13-21.

Štrba L., Rybár P., Baláž B., Molokáč M., Hvizdák L., Kršák B., Lukáč M., Muchová L., Tometzová D., Ferenčíková J., 2015. Geosite assessments: comparison of methods and results. Current Issues in Tourism, 18: 496-510.

Śliwa Z., 1967. Własności strukturalne bazaltów Śląska. Rocznik Polskiego Towarzystwa Geologicznego, 37: 435-454.

Tomić N., Božić S. 2014. A modified Geosite Assessment Model (M-GAM) and its Application on the Lazar Canyon area (Serbia). International. Journal of Environmental Research, 8: 1041-1052.

Zouros N.C., 2007. Geomorphosite assessment and management in protected areas of Greece, case study of the Lesvos island - coastal geomorphosites. Geographica Helvetica, 62: 169-180. 